\title{
The development of macros program-based cognitive evaluation model via e-learning course mathematics in senior high school based on curriculum 2013
}

\author{
Djoko Purnomo $^{1}$, Harjito $^{2}$, Rina Dwi Setyawati ${ }^{3}$ and Muhammad Prayito ${ }^{4}$ \\ ${ }^{1,3,4}$ FPMIPA, UNIVERSITAS PGRI SEMARANG \\ ${ }^{2}$ FPBS, UNIVERSITAS PGRI SEMARANG
}

email: 'djokopurnomo@ikippgrismg.ac.id, ${ }^{2}$ harjito96@yahoo.co.id, ${ }^{3}$ budirina15@gmail.com, 4mprayito@gmail.com

\begin{abstract}
The specific purpose of this research is: The implementation of the application of the learning tool with a form cognitive learning evaluation model based macros program via E-learning at High School grade $\mathrm{X}$ at july-december based on 2013 curriculum. The method used in this research followed the procedures is research and development by Borg and Gall [2]. In second year, population analysis has conducted at several universities in Semarang. The results of the research and application development of macro program-based cognitive evaluation model is effective which can be seen from (1) the student learning result is over KKM, (2) The student independency affects learning result positively, (3) the student learning a result by using macros program-based cognitive evaluation model is better than students class control. Based on the results above, the development of macros program-based cognitive evaluation model that have been tested have met quality standards according to Akker (1999). Large-scale testing includes operational phase of field testing and final product revision, i.e trials in the wider class that includes students in mathematics education major in several universities, they are the Universitas PGRI Semarang, Universitas Islam Sultan Agung and the Universitas Islam NegeriWalisongo Semarang. The positive responses is given by students at the Universitas PGRI Semarang, Universitas Islam Sultan Agung and the Universitas Islam NegeriWalisongo Semarang.
\end{abstract}

\section{Introduction}

The main problem in senior high school teaching learning faced by teachers based on curriculum 2013 is the changes of both student and teacher mindset in doing teaching activity. The implementation of the changing of curriculum KTSP to 2013 emphasizes the develompent in refinement of mindset, strengthening curriculum managing system, deepening and expansion matter, strengthening teaching process and fitting the study load so that it is guaranted that there is a conformity beetwen expectations and results. Developing curriculum is getting more important as the continuities of the progress of science, technology and art and the changes of society in local, regional, national and global level in the future. They create internal and external challenges in education. That's why the implementation of curriculum 2013 is the strategic step to face the globalization and society demands in future. 
As the change of curriculum 2013, the teaching process emphasizes the active learning and teachers will focus on teaching process guide while doing the authentic evaluation, whether in cognitive, affective and psichomotoric aspect. The appraisal in each teaching process will increase the teacher's load, according to teching load, range about 6 classes with students almost $6 \times 30=180$. In one semester there are 8 main matter. If in each matter there is 3 times competence test then there are $8 \times 3 \times 180=$ 4.320 students. Beside that, teacher must do the other responsibilities, they are doing affective evaluation, work show, project and portofolio.

The development of science and technology that are getting faster and faster makes the informations are accessed easily by using internet. This media is growing as the growing of communication and information technology. Because of that, it is very possible to develop several new teaching models [8]. One of the models is macros program-based cognitive evaluation model. Internet is such a window to see the world that significantly give many contributions in education which the users should conform with the teaching needs [6].

Wood, Cobb, and Yackel declare that mathematics shouldn't be regarded as the objective knowledge but should be regarded as the active construction of an individu that is shared and understood by the other individu. Then an independency in the teaching process is needed to construct the knowledge [9] and E-Learning teaching is one of the teaching media alternative to give the solution of that problem [7].

Begin from those thoughts, it is possible to develop the program macros-based cognitive evaluation model. This program can be created by using net system/LAN in School labolatorium or by preparing $\mathrm{CD}$ /flash disk that can be used by each student on their laptop/PC [3].

\section{Methods}

The reasearch method that is used in this study is following the R\&D procedures that is developed by Borg and Gall [2]. The population is student in Mathematics Education Major in University in Semarang. While the sampel is student of mathematics education major Universitas PGRI Semarang, Universitas Islam Negeri Walisongo Semarang, and Universitas Islam Sultan Agung in semester 4. The data collection technique is following the documentation method, testing method, observation method and questionnaire method.

\section{Result and Dicussion}

Validation of macros program-based cognitive evaluation model consists of main field testing and operational product revision. The trials conducted in class was aimed to test the appropriateness of the evaluation model implementation (second prototype). Then the third prototype is tested to the class experiment. Population in this trials is students in semester 4 that have been taking Senior High School mathematics course. While the sample is taken according to purposive random sampling, consists of student of mathematics education program Universitas PGRI Semarang. 


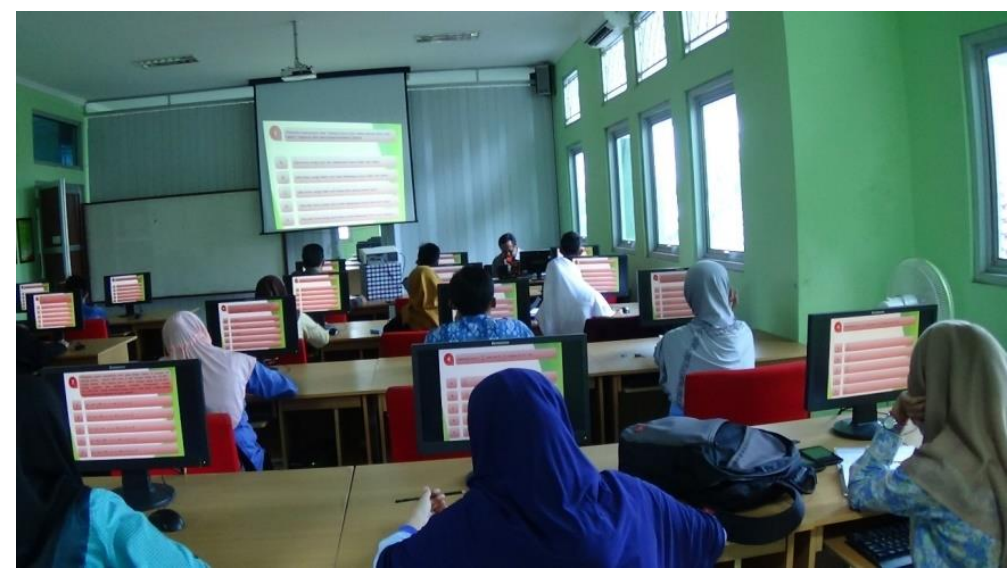

Figure 1. The use of macros program-based evaluation tool

Teaching by development of macros program-based evaluation tool is effective. It can be seen from (1) the student learning result is over KKM, (2) The student independency affects learning result positively, (3) the student learning result by using macros program-based cognitive evaluation model is better than the study of students grade control. Based on the results above, the development of macros program-based cognitive evaluation model that have been tested have met quality standards according to Akker [1].

Problems that are given to students are mathematics problems in grade 10,11 and 12 . They are 30 with duration 90 minutes. First display in this program is about the matter or chapter of the problems. Second display is the direction of solving the problems using macros program. Before go to the first problem, students will be asked to fill their name and student ID Number or NIM (Nomor Induk Mahasiswa). Afterwards, the student will see the result. The figure of the problems in macros program-based evaluation tool is diplayed below.

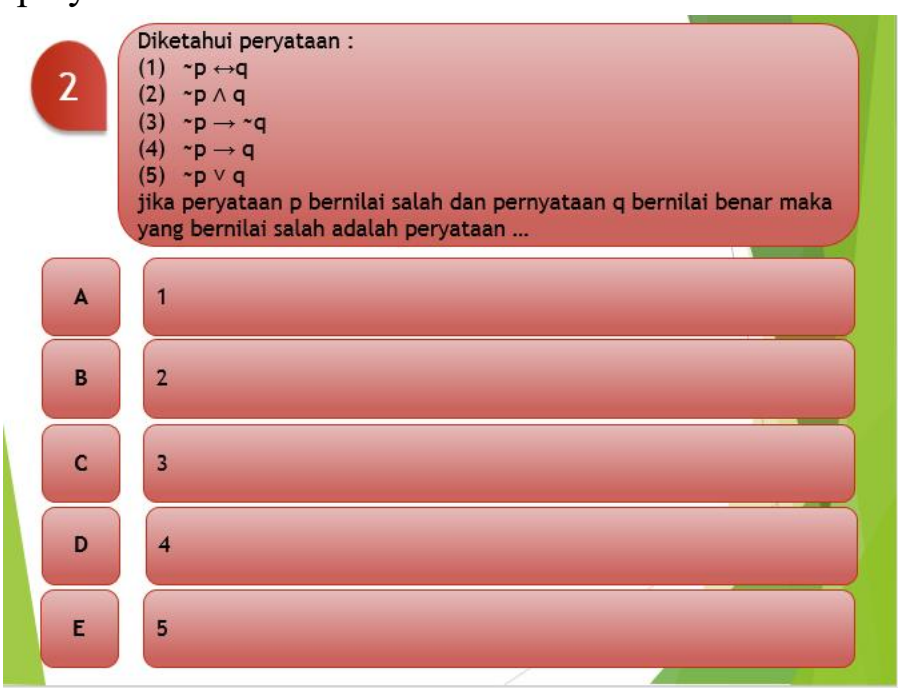

Figure 2. Display of the problems in macros program-based evaluation tool

The wide scale testing consists of operational field testing and final product revision. It is a testing in a wider class that covers the students in mathematics education program from Universitas Islam Negeri Walisongo Semarang and Universitas Islam Sultan 
Agung. Based on the result of this trial, we collect the students responses corresponds to the using of macros program-based cognitive evaluation tool. The students give the positive responses. It means they agree with the development of macros program-based cognitive evaluation model. These following lists are the additional notes that complete the students responses (The same response is not rewritten).

1) It is necessary to add the tittle of the matter or chapter in each problem so that it will help in solving the problem.

2) It is needed to add the animation to help student to get relax in solving the problem.

3) In teaching process, it will be better if in each problem is including the steps of the solving of the problem.

4) It will be better if there are displayed "NEXT" and "BACK" button then student can start from the easier problems

5) The difficulty level of the problems doesn't conform with the duration given.

6) Students expect to be given the outlines of the problem first

7) If it's possible, Students expect the notes about their mistakes in solvin the problem so that they can revise their work.

8) Decrease the difficulty level

9) It will be interesting if the evaluation problems are more diversified.

10) The students expect that the teachers can make the macros program-based evaluation tools so that can decrease the use of papers.

11) It's good and motivating the next researcher to develop the further tools or models. 


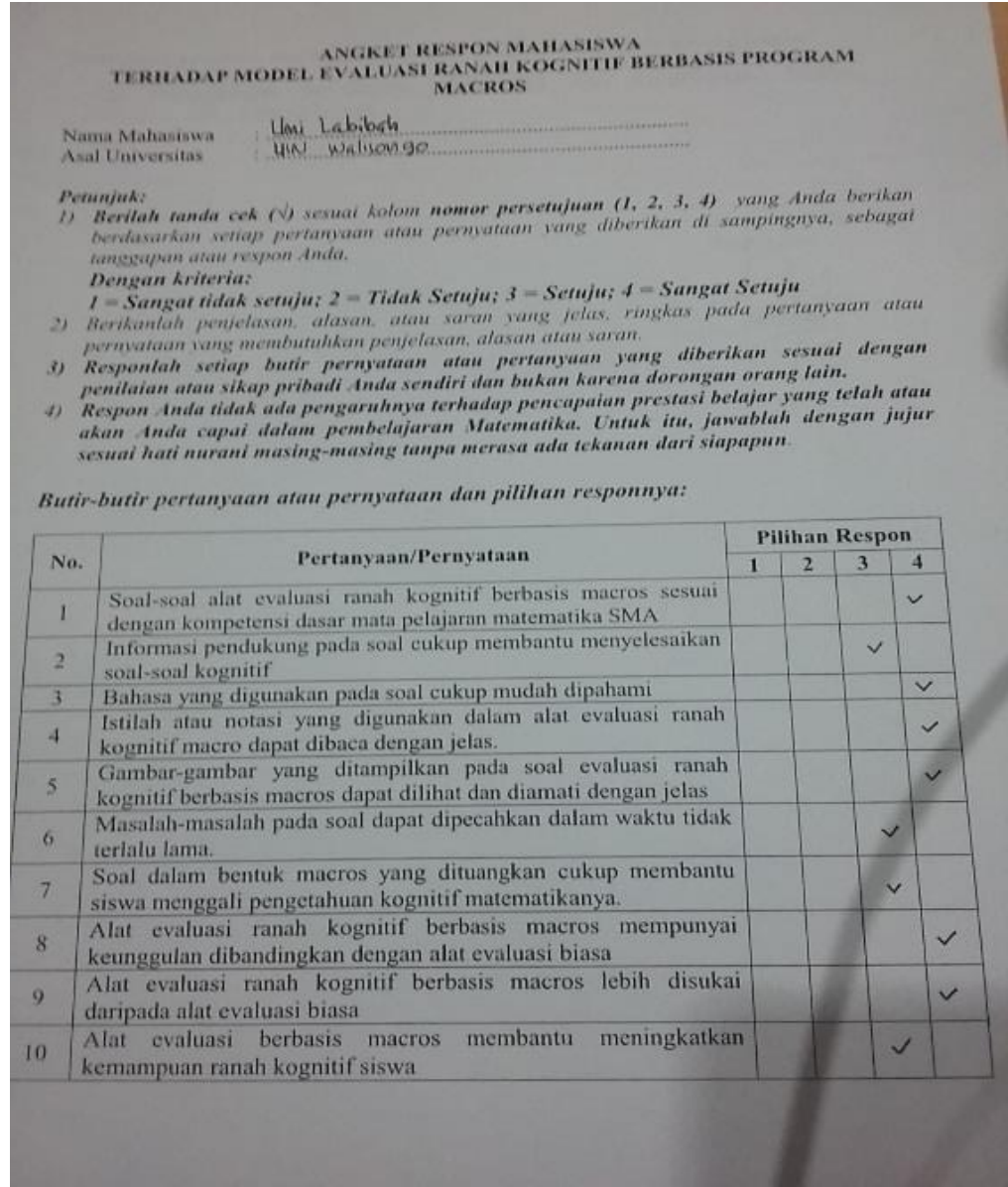

Figure 3. One of the questionnaires that is filled by student

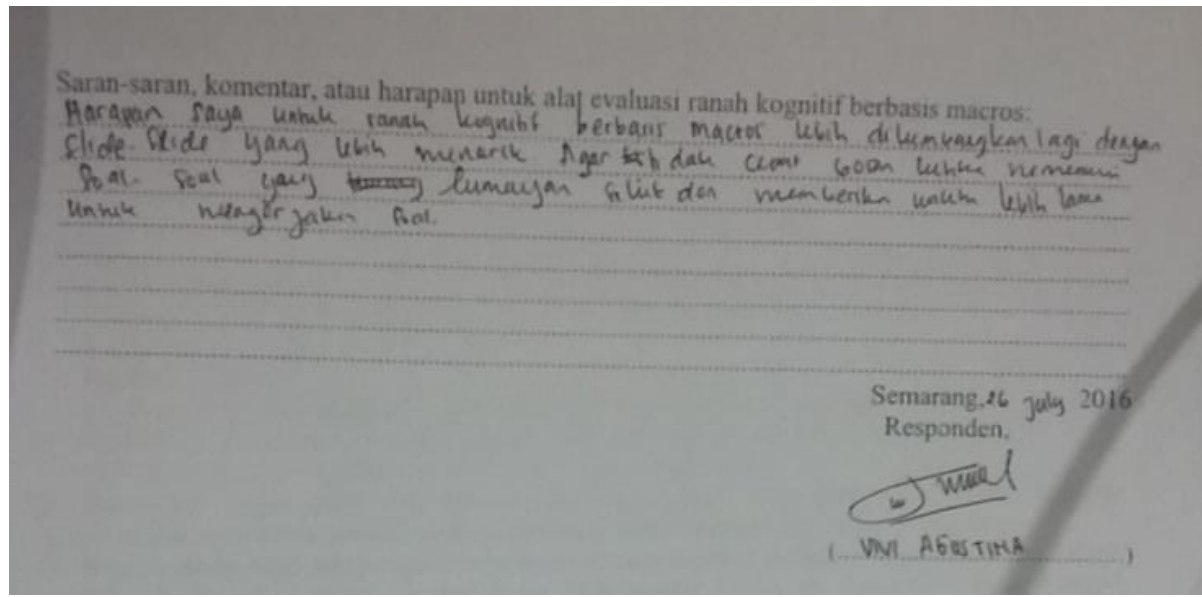

Figure 4. One of the students responses

Based on the responses and suggestions from students of Universitas Islam Negeri walisongo semarang and Universitas Islam Sultan Agung dilakukan revisi, we will make the improvement and conformity. The product that has been tested must satisfy the quality criteria. Akker (1999) declare that 3 quality criterias are: Validity, practicality and effectivity. 
Table 1. The result of student response questionnaire

\begin{tabular}{|c|c|c|}
\hline No. & Question/Statement & Result \\
\hline 1 & $\begin{array}{l}\text { The problems in macros program-based cognitive evaluation tools are } \\
\text { corresponding with the basic competency of senior high school } \\
\text { mathematics. }\end{array}$ & $79 \%$ \\
\hline 2 & $\begin{array}{l}\text { The supporting information in each problem is helping enough to solving } \\
\text { the cognitive problems }\end{array}$ & $86 \%$ \\
\hline 3 & The diction in the problem is easy enough to be understood. & $91 \%$ \\
\hline 4 & $\begin{array}{l}\text { The notations and terms that appear in the macro program-based } \\
\text { cognitive evaluation tool are clearly readable. }\end{array}$ & $75 \%$ \\
\hline 5 & $\begin{array}{l}\text { Graphics or figures that are displayed on macro program-based cognitive } \\
\text { evaluation tool can be seen clearly. }\end{array}$ & $92 \%$ \\
\hline 6 & The problems can be solved in no time. & $74 \%$ \\
\hline 7 & $\begin{array}{l}\text { The problems in macros form that are used are helping enough to } \\
\text { explore the mahematics cognitive knowledge of the students. }\end{array}$ & $78 \%$ \\
\hline 8 & $\begin{array}{l}\text { Macro program-based cognitive evaluation tool has the excesses } \\
\text { compare with ordinary evaluation tools. }\end{array}$ & $91 \%$ \\
\hline 9 & $\begin{array}{l}\text { Macro program-based cognitive evaluation tool is more preferable than } \\
\text { ordinary evaluation tools. }\end{array}$ & $86 \%$ \\
\hline 10 & $\begin{array}{l}\text { Macro program-based cognitive evaluation tool helps to increase the } \\
\text { student cognitive ability. }\end{array}$ & $77 \%$ \\
\hline \multicolumn{2}{|r|}{ Total } & $83 \%$ \\
\hline
\end{tabular}

Result percentage which shows that macro program-based cognitive evaluation tool is more preferable than ordinary evaluation tools is $86 \%$. It means that students like macro program-based cognitive evaluation tool more than manual evaluation tool. Total percentage of the student response questionnaire score is $83 \%$ and it means students agrre of the using of macro program-based cognitive evaluation tool. This result agree with Brown[3], Guksey[5] and wagner[10]. The excesses in macros give attractiveness to students. On the interview with students, thet are interesting to use the macro program-based cognitive evaluation tool because it makes easy in correcting the answer.

\section{Conclusions}

Based on the development of macro program-based cognitive evaluation model we can conclude that process and development result is valid in first year and in second year we apply the model and the result shows that the model is effective which can be seen from (1) the student learning result is over KKM, (2) The student independency affects learning result positively, (3) the student learning result by using macros program-based cognitive evaluation model is better than the study of students grade control. Based on the results above, the development of macros program-based cognitive evaluation model that have been tested have satisfied quality standards according to Akker (1999). 
Large-scale testing includes operational phase of field testing and final product revision, i.e trials in the wider class that includes students in mathematics education major in several universities, they are the Universitas PGRI Semarang, Universitas Islam Sultan Agung and the Universitas Islam NegeriWalisongo Semarang. The positive responses is given by students at Universitas PGRI Semarang, Universitas Islam Sultan Agung and Universitas Islam NegeriWalisongo Semarang.

\section{References}

[1] Akker, J. Van den. 1999. Principles and Method of Development Research. London. Kluwer Academic Publisher.

[2] Borg, W.R. and Gall, M.D. (1983). Educational Research: An Introduction. London: Longman, Inc.

[3] Brown, S. 2001. Campus Re-engineering-Innovation in Open\& Distance Learning: Successful development of online and web-based learning. London: Kogan Page Limited.

[4] Chen, X. 2009. Design and Application of a General-purpose E-Learning Platform. International Journal of Business and Management. 4/9:178-181.

[5] Guskey, T. 1982. The Effectiveness of Mastery Learning Strategies in Undergraduate Education Courses. New York

[6] Koohang, A. 2009. E-Learning and Constructivism: From Theory to Application. Journal of E-Learning and Learning Objects. 5: 91-100.

[7] Manuela Paechter, Brigitte Maier (2010), Online or face-to-face? Students' experiences and preferences in ICT, The Internet and Higher Education, Volume 13, Issue 4, December 2010, Pages 292-29.

[8] Ritz, J. M. 2009. A New Generation of Goals for Technology Education. Journal of Technologi Education, 20/2:50-64.

[9] Rong, Z. et. Al. 2008. Designing and implementing the E-Learning System. International Conference on Computer Science and Software Engineering. Available ftp://ftp.computer.org/press/outgoing/proceedings/csse08/data/3336i797.pdf [ac cessed 13/02/2011]

[10] Wagner, N. 2008. Who is responsible for E-Learning Success in Higher Education? A Stakeholders' Analysis. Educational Technology \& Society, 11/3, 26-36. 